J. Dairy Sci. 95:2261-2269

http://dx.doi.org/10.3168/jds.2011-4582

(C) American Dairy Science Association ${ }^{\circledR}, 2012$.

\title{
Probiotic yogurts manufactured with increased glucose oxidase levels: Postacidification, proteolytic patterns, survival of probiotic microorganisms, production of organic acid and aroma compounds
}

\author{
A. G. Cruz, ${ }^{* 1}$ W. F. Castro, ${ }^{\star}$ J. A. F. Faria, ${ }^{\star}$ P. C. B. Lollo, ${ }^{\star}$ J. Amaya-Farfán, ${ }^{\star}$ M. Q. Freitas, $†$ D. Rodrigues, ${ }^{\star}$ \\ C. A. F. Oliveira, $\neq$ and H. T. Godoy* \\ *Universidade Estadual de Campinas (UNICAMP), Faculdade de Engenharia de Alimentos (FEA), Cidade Universitária Zeferino Vaz, 13083-862, \\ Campinas, São Paulo, Brazil \\ †Universidade Federal Fluminense (UFF), Faculdade de Veterinária, Niterói, CEP 24230-340, Niterói, Rio de Janeiro, Brazil \\ łUniversidade de São Paulo (USP), Faculdade de Zootecnia e Engenharia de Alimentos Campus da USP (FZEA), Pirassununga, \\ CEP 13635-900, São Paulo, Brazil
}

\begin{abstract}
We investigated the effect of increased glucose oxidase concentration as a technological option to decrease oxidative stress during the processing of probiotic yogurts. Probiotic yogurts were produced with increased concentrations of glucose oxidase $(0,250,500,750$, or $1,000 \mathrm{mg} / \mathrm{kg}$ ) and submitted to physicochemical and microbiological analysis at 1, 15, and $30 \mathrm{~d}$ of refrigerated storage. Higher concentrations of glucose oxidase (750 and $1,000 \mathrm{mg} / \mathrm{kg}$ ) and a longer storage time were found to have an influence on the characteristics of the probiotic yogurt, contributing to more extensive postacidification, an increase in the dissolved oxygen level, and higher proteolysis. In addition, increased production of aroma compounds (diacetyl and acetaldehyde) and organic acids (mainly lactic acid) and a decrease in the probiotic bacteria count were reported. The use of glucose oxidase was a feasible option to minimize oxidative stress in probiotic yogurts. However, supplementation with excessive amounts of the enzyme may be ineffective, because insufficient substrate (glucose) is present for its action. Consumer tests should be performed to evaluate changes in the sensory attributes of the probiotic yogurts with increased supplementation of glucose oxidase. In addition, packaging systems with different permeability to oxygen should be evaluated.

Key words: glucose oxidase, probiotic yogurt, oxidative stress
\end{abstract}

\section{INTRODUCTION}

The consumer preference for yogurt as a vehicle for probiotic culture is much more related to the reputation

Received May 29, 2011.

Accepted November 13, 2011.

${ }^{1}$ Corresponding author: food@globo.com of a naturally healthy product in the consumer's mind than to the technological obstacles involved in its production (Zhu et al., 2009; Johansen et al., 2010; Sanders and Marco, 2010). Considering the food matrices that may be supplemented with probiotic microorganisms, such as soy, meat, cereal and fruit juices (Granato et al., 2010a; Rivera-Espinoza and Gallardo-Navarro, 2010), fruit (Alegre et al., 2011), cheeses (Bergamini et al., 2009; Albenzio et al., 2010; Gomes et al., 2011; Madureira et al., 2011a,b; Minervini et al., 2012) or ice creams (Di Criscio et al., 2010; Isik et al., 2011; Ferraz et al., 2012), yogurts and fermented milks are the most popular food carriers (Almeida et al., 2008; Oliveira et al., 2009, 2011; Allgeyer et al., 2010; Cruz et al., 2010b, 2012; Mortazavian et al., 2010; Marafon et al., 2011), and it is widely known that the consumption of probiotic products may confer many health benefits (Ejtahed et al., 2011; Ramchandran and Shah, 2011; Savard et al., 2011). Recently, Saxelin et al. (2010) demonstrated that yogurts and fermented milks were as effective as capsules for the administration of probiotic bacteria, emphasizing the importance of such matrices as functional food matrices.

Obtaining desirable therapeutic effects in probiotic dairy products such as yogurts and fermented milks requires the viability of the probiotic bacteria to be maintained at a sufficient level throughout storage of the product. It has been suggested that probiotics should be present in the food product in minimal amounts of $10^{6} \mathrm{cfu} / \mathrm{g}$, representing a daily dose of $10^{8} \mathrm{cfu} / \mathrm{g}$, to compensate for a possible reduction in this number during passage through the gastrointestinal tract (Granato et al., 2010a,b; Figueroa-González et al., 2011). From a technological standpoint, the processing of yogurt supplemented with probiotic cultures is not easy, particularly with respect to maintaining the viability of the cultures (Corcoran et al., 2008). One problem is that of oxidative stress, which is caused by exposure to oxygen permeating through the plastic packaging 
material during refrigerated storage (Granato et al., 2010a). To overcome the problem of oxidative stress, technological alternatives have been proposed. These include the addition of chemical compounds aimed at achieving a chemical solution called the destressing effect (Zhao and Li, 2008); the addition of Lactococcus lactis to milk intended to be used in the manufacture of yogurt to reduce its oxi-reduction potential (Jeanson et al., 2009; Yonezawa et al., 2010; Odamaki et al., 2011); the addition of nitrogen simultaneously with the addition of cultures during yogurt processing, followed by fermentation at $37^{\circ} \mathrm{C}$ (Horiuchi et al., 2009); the addition of gases to modify the redox potential (Ebel et al., 2011); and even the development of oxygen-tolerant strains (Li et al., 2010). Indeed, maintaining the viability of probiotic strains in dairy foods is still a challenge for the industry once many metabolic conditions (e.g., sensitivity to oxygen) need to be taken into account in order to develop a functional food that exerts a therapeutic function. Immobilization on different polymers (Rodrigues et al., 2011), manipulation of incubation temperature, final $\mathrm{pH}$ of fermentation (Shafiee et al., 2010), and even music waves (Mohammadi et al., 2011) are recent approaches to improve the viability of probiotic bacteria in probiotic fermented milks and yogurts.

The use of a glucose-glucose oxidase enzyme complex has been proposed as a viable alternative to reduce the oxygen dissolved in the product and consequently maintain Bifidobacterium longum counts at levels capable of delivering benefits to the consumer. Using this approach and surface response methodology, predictive models were obtained and validated, and glucose oxidase was found to be the variable of greatest importance for predicting B. longum counts (Cruz et al., 2010a), suggesting that the addition of increasing levels of the enzyme may have a positive effect on the probiotic status of the product. This research aimed to evaluate the effect of increased levels of glucose oxidase in the processing of probiotic yogurts. Postacidification, proteolytic patterns, survival of probiotic bacteria, and the production of organic acid and aroma compounds were evaluated during refrigerated storage.

\section{MATERIALS AND METHODS}

\section{Culture Growth}

Pure cultures of Streptococcus thermophilus TA040, Lactobacillus delbrueckii ssp. bulgaricus LB340, Bifidobacterium longum BL05, and Lactobacillus acidophilus La14 were obtained from Danisco (São Paulo, Brazil) and maintained at $-80^{\circ} \mathrm{C}$. The $B$. longum strain was chosen due its higher sensitivity to oxygen compared with other Bifidobacterium strains (Simpson et al.,
2005; Kawasaki et al., 2006; Jayamane and Adams, 2009; Fortin et al., 2010).

Skim milk powder (Molico, São Paulo, Brazil), reconstituted to $11 \%$ (wt/vol), was used to prepare the lactic and probiotic cultures. For B. longum BL05, 0.05\% (wt/vol) cysteine (Sigma, São Paulo, Brazil) and $0.5 \%$ (wt/vol) yeast extract (Oxoid, São Paulo, Brazil) were added to the milk powder reconstituted to $11 \%$, whereas for the other lactic and probiotic cultures, the reconstituted skim milk was supplemented with $2 \%$ (wt/vol) glucose (Synth, São Paulo, Brazil). All the reconstituted milks were autoclaved at $115^{\circ} \mathrm{C}$ for 10 min, and the cysteine solution used was sterilized by membrane filtration.

\section{Yogurt Processing}

The probiotic stirred yogurts were produced using a standard yogurt manufacturing process (Tamime and Robinson, 2007), the operational parameters such as fermentation temperature being tested previously (Cruz et al., 2010a, 2011). Raw milk standardized with skim milk powder at $3.5 \%$ (wt/vol; Atilatti, Itatiba, Brazil) was submitted to heat treatment $\left(95^{\circ} \mathrm{C}\right.$ for 15 min), cooled to $45^{\circ} \mathrm{C}$, and inoculated simultaneously with $1 \%$ (vol/vol) Strep. thermophilus TA040, 1\% (vol/ vol) Lb. delbrueckii ssp. bulgaricus LB340, $2 \%$ (vol/ vol) B. longum BL05, and $2 \%$ (vol/vol) Lb. acidophilus La14. The inoculated milk was subsequently submitted to fermentation at $45^{\circ} \mathrm{C}$, with the $\mathrm{pH}$ monitored until it reached values of $4.6 \pm 0.05$. The mixture was then cooled to $10^{\circ} \mathrm{C}$ and the gel was broken by manually stirring it for $10 \mathrm{~min}$. Because stirring is the last step that incorporates oxygen during yogurt processing, the glucose oxidase was added during stirring so more consistent results could be obtained. Powdered glucose oxidase (Glucomax CO, Prozyn, São Paulo, Brazil; contained catalase in the formulation) previously dissolved in $100 \mathrm{~mL}$ of deionized water was added to yield concentrations of $0,250,500,750$, and $1,000 \mathrm{mg} / \mathrm{kg}$ $\left(\mathbf{Y}_{0}, \mathbf{Y}_{250}, \mathbf{Y}_{500}, \mathbf{Y}_{750}\right.$, and $\mathbf{Y}_{1000}$, respectively), based on preliminary tests and economic considerations regarding the addition of the enzyme.

Finally, the probiotic yogurts were packaged in 100$\mathrm{mL}$ polypropylene pots (permeability of $0.20 \mathrm{~cm}^{3}$ of $\mathrm{O}_{2}$ per pot-day, Dixie Toga, São Paulo, Brazil) and stored $\left(3-5^{\circ} \mathrm{C}\right)$ for $30 \mathrm{~d}$. Physicochemical and microbiological analyses were conducted at 1,15 , and $30 \mathrm{~d}$.

\section{Microbiological Analysis}

The Strep. thermophilus TA040 count was quantified using M17 agar (Oxoid) following incubation under aerobiosis at $37^{\circ} \mathrm{C}$ for $48 \mathrm{~h}$, whereas the $L b$. bulgaricus 
LB 340 count was quantified on de Man, Rogosa, and Sharpe agar (Oxoid) at pH 5.2 (adjusted with glacial acetic acid) and under anaerobiosis at $45^{\circ} \mathrm{C}$ for $72 \mathrm{~h}$ (Rybka and Kailasapathy, 1996). The B. longum BL05 count was quantified using lithium chloride-sodium propionate agar containing $0.5 \mathrm{~g} / \mathrm{L}$ of $\mathrm{LiCl}$ and 0.75 $\mathrm{g} / \mathrm{L}$ of $\mathrm{NaCl}$, heat sterilized, Sigma), and the plates were incubated under anaerobiosis at $37^{\circ} \mathrm{C}$ for $72 \mathrm{~h}$ (Zacarchenco and Roig, 2004). Lactobacillus acidophilus counts were carried out on de Man, Rogosa, and Sharpe agar supplemented with $0.15 \%$ (wt/vol) bile salts (Oxoid), incubated at $37^{\circ} \mathrm{C}$ for $72 \mathrm{~h}$ under aerobic conditions (Mortazavian et al., 2007). All the culture media were tested previously to ensure their selectivity for the specific microorganisms. Microbiological analyses were carried out in triplicate.

\section{Physicochemical Analysis}

The probiotic stirred yogurts were submitted to the following analyses at 1, 15, and $30 \mathrm{~d}$ of refrigerated storage using methodologies published elsewhere: $\mathrm{pH}$ (Marshall, 1993); proteolytic activity using the ophthaldialdehyde (OPA) method (Church et al., 1983); oxygen dissolved (Cruz et al., 2010a); glucose, lactic acid, and acetic acid contents (Donkor et al., 2005); and diacetyl and acetaldehyde (Condurso et al., 2008) contents. The physicochemical analyses were carried out in triplicate.

\section{Statistical Analyses}

The experiment was repeated 3 times. Two one-way ANOVA were carried out: the first used sample and the second used storage time as the source of variation. These calculations were followed by Tukey's test; $P<$ 0.05 was considered significant. All analyses were carried out using Statistica 7.1 software (StatSoft, Tulsa, $\mathrm{OK})$.

\section{RESULTS AND DISCUSSION}

\section{Postacidification, Oxygen Levels, and Proteolysis}

Table 1 shows the values for $\mathrm{pH}$, dissolved oxygen, and proteolysis in the probiotic yogurts supplemented with increasing concentrations of glucose oxidase. Overall, the concentration of glucose oxidase throughout the storage time $(P<0.05)$ was found to affect the characteristics of the finished product compared with the control yogurt $\left(\mathrm{Y}_{0}\right)$.

The addition of greater amounts of enzyme to the yogurts $\left(\mathrm{Y}_{750}\right.$ and $\left.\mathrm{Y}_{1000}\right)$ induced more extensive postacidification, as expressed by the lower $\mathrm{pH}$ values $(4.12$ and 4.07 at $30 \mathrm{~d}$, respectively), and a sharp increase in the amount of dissolved oxygen $(6.79$ and $7.12 \mathrm{~g} / \mathrm{L}$ at $30 \mathrm{~d}$, respectively), the latter being comparable to that of the control yogurt $(7.74 \mathrm{~g} / \mathrm{L})$ and intermediate levels of proteolysis (absorbance of 0.678 and 0.698 , respectively) during storage. On the other hand, the

Table 1. pH, oxygen content, and proteolysis in probiotic yogurts with increased glucose oxidase concentrations during refrigerated storage ${ }^{1}$

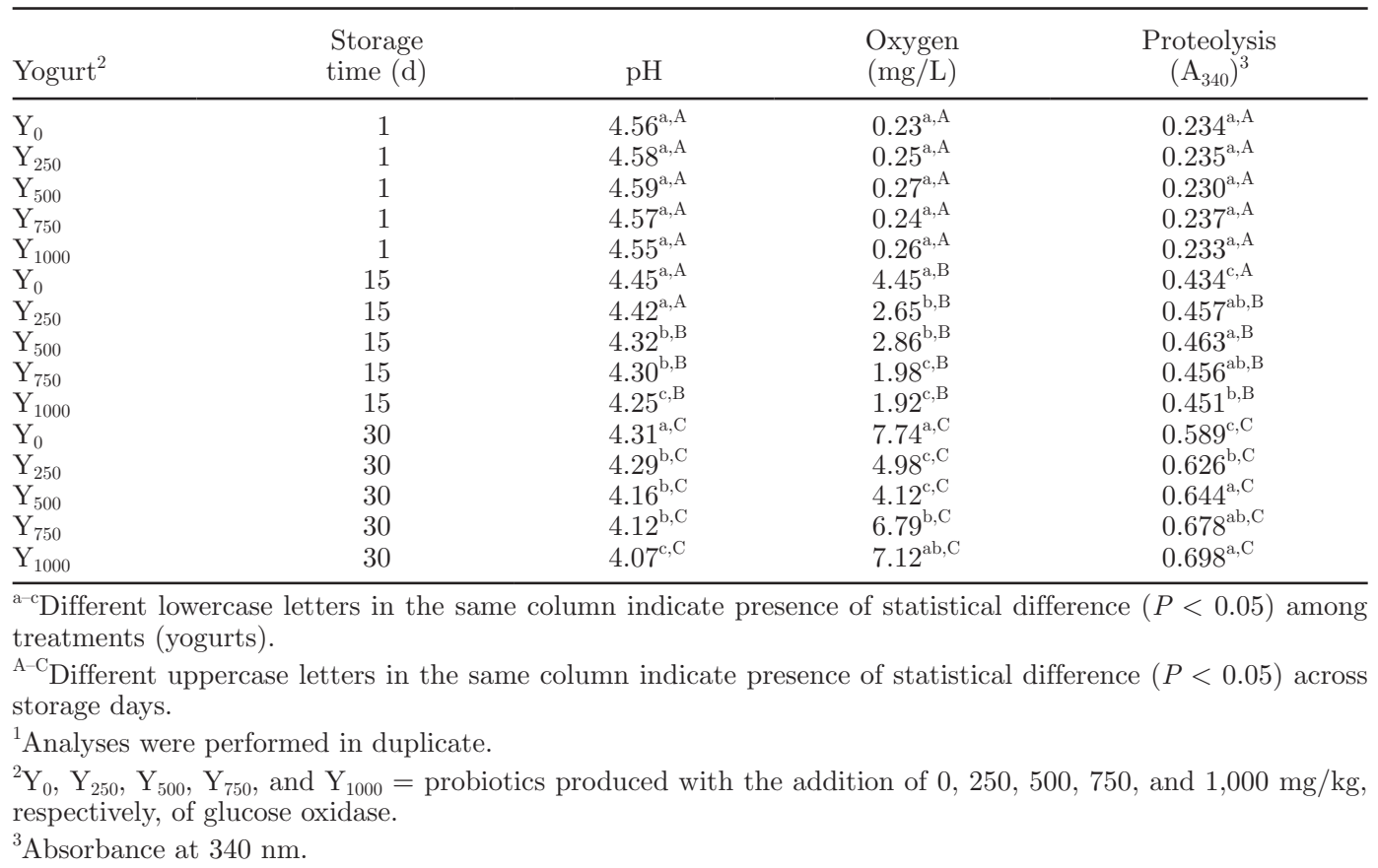


addition of intermediate levels $\left(Y_{250}\right.$ and $\left.Y_{500}\right)$ led to a lesser increase in the levels of dissolved oxygen (4.98 and $4.12 \mathrm{~g} / \mathrm{L}$ at $30 \mathrm{~d}$, respectively), and intermediate $\mathrm{pH}$ (4.29 and 4.16, respectively) and proteolysis values (absorbance of 0.626 and 0.644 , respectively) throughout the storage period. The results suggest that if, on the one hand, the naturally low $\mathrm{pH}$ values of yogurt enhance the importance of an additional amount of glucose oxidase, then, on the other hand, supplementation with excessive amounts may be ineffective because no glucose is available (glucose is the substrate necessary for activating the glucose oxidase). In this way, intermediate amounts of the enzyme yield favorable results throughout the shelf life; that is, low values of dissolved oxygen and milder postacidification and proteolysis, with a significant effect on the economic aspects of production.

Probiotic bacteria, particularly bifidobacteria, are sensitive to low $\mathrm{pH}$ values and demonstrate variable proteolytic activity depending on the specific strain (Shihata and Shah, 2000; Jayamane and Adams, 2009) as a function of the presence of the FoF1-ATPase enzyme (van de Guchte et al., 2002). However, the decrease in $\mathrm{pH}$ during refrigerated storage is one of the main factors responsible for the poor viability of this microbial group throughout the shelf life of probiotic yogurts (Shah, 2000; Granato et al., 2010b). Strategies used to minimize the effect of the acid stress during probiotic yogurt processing include adequate selection of strains (Godward et al., 2000) and adaptation of the probiotic strain to sublethal stress conditions. Other artifices include the use of selected or genetically modified strains of $L b$. bulgaricus with slower metabolic rates, which results in a slower decline in $\mathrm{pH}$ and decreased proteolytic activity (Ongol et al., 2007), and microencapsulation (Burgain et al., 2011). However, excluding $L b$. bulgaricus from the yogurt-making process, which would seem to be the most practical and economic alternative, would have regulatory implications because it would decharacterize the product. According to Brazilian regulations, a conventional yogurt must contain at least $7 \mathrm{log} \mathrm{cfu} / \mathrm{g}$ of viable lactic bacteria cells (Brasil, 2007).

Exposure to oxygen is detrimental for the metabolism and survival of Bifidobacterium species as they present anaerobic metabolism. The oxidative damage is related to the production of reactive oxygen species, and the bacteria tolerance to this stress is associated to presence of some enzymes and also changes in morphology and components on the cell surface (Ruiz et al., 2011) and this effect is strain-dependent. An increase in the growth of $B$. longum during the lag phase and some morphological modifications as well as changes in the fatty acid profile have already been reported (Ahn et al., 2001), whereas, for B. animalis ssp. lactis Bb12, changes in the surface hydrophobicity and an increase in protein content in the presence of increased oxygen concentration was observed by Shakirova et al. (2010) Other factors to be considered are that aerobic conditions decrease the production of exopolysaccharides in some bifidobacteria strains, such as B. longum (Ninomiya et al., 2009), and this can be considered negative, as exopolysaccharides are able to increase viscosity and confer a desirable texture to the fermented product (Salazar et al., 2009).

Minimizing oxidative stress in the processing of probiotic yogurts has been extensively researched for maintenance of viable probiotic bacteria counts, with several alternative technologies being proposed. Recently, it was reported that addition of nitrogen during yogurt processing simultaneously with the addition of the cultures and subsequent fermentation at $37^{\circ} \mathrm{C}$ could result in a decrease in the amount of dissolved oxygen in the product before the production of acids (Horiuchi et al., 2009).

Our findings presented results that are comparable to previous technological solutions, such as the addition of ascorbic acid or other ingredients that are used to minimize the oxidative stress caused by oxygen (Dave and Shah, 1997, 1998), milk electroreduction (Bolduc et al., 2006), the use of polystyrene laminated to high-gas-barrier material (Miller et al., 2002), active packaging systems (Miller et al., 2003), microencapsulation (Talwalkar and Kailasapathy, 2004), the use of plastic packaging systems with different polarities and crystallinities (Jasson et al., 2001), and the use of Oxyrase (Oxyrase Inc., Mansfield, OH), which reduces fractions of bacterial cell membranes (Ordonez et al., 2000). The supplementation of probiotic yogurts with intermediate glucose oxidase concentrations decreased the oxygen level and provided intermediate proteolysis values during yogurt storage. Although it is possible to induce adaptations to oxidative stress in probiotic bacteria (Talwalkar and Kailasapathy, 2004), it is a time-consuming task, whereas the addition of glucose oxidase during yogurt processing is a simple option, available to small and medium-sized dairy processors.

\section{Microbial Counts}

Table 2 shows the viable counts of Strep. thermophilus, Lb. bulgaricus, B. longum, and Lb. acidophilus in probiotic yogurts supplemented with increasing quantities of glucose oxidase. Immediately upon completion of fermentation, counts of $9.38,8.53,8.01$, and $8.6 \log \mathrm{cfu} /$ $\mathrm{mL}$ were recorded for these microorganisms, respectively, suggesting that this step did not have a negative effect on the growth of probiotic and starter microor- 
Table 2. Microbiological viable count of probiotic and starter bacteria in probiotic yogurts with increased glucose oxidase concentrations during the refrigerated storage ${ }^{1}$

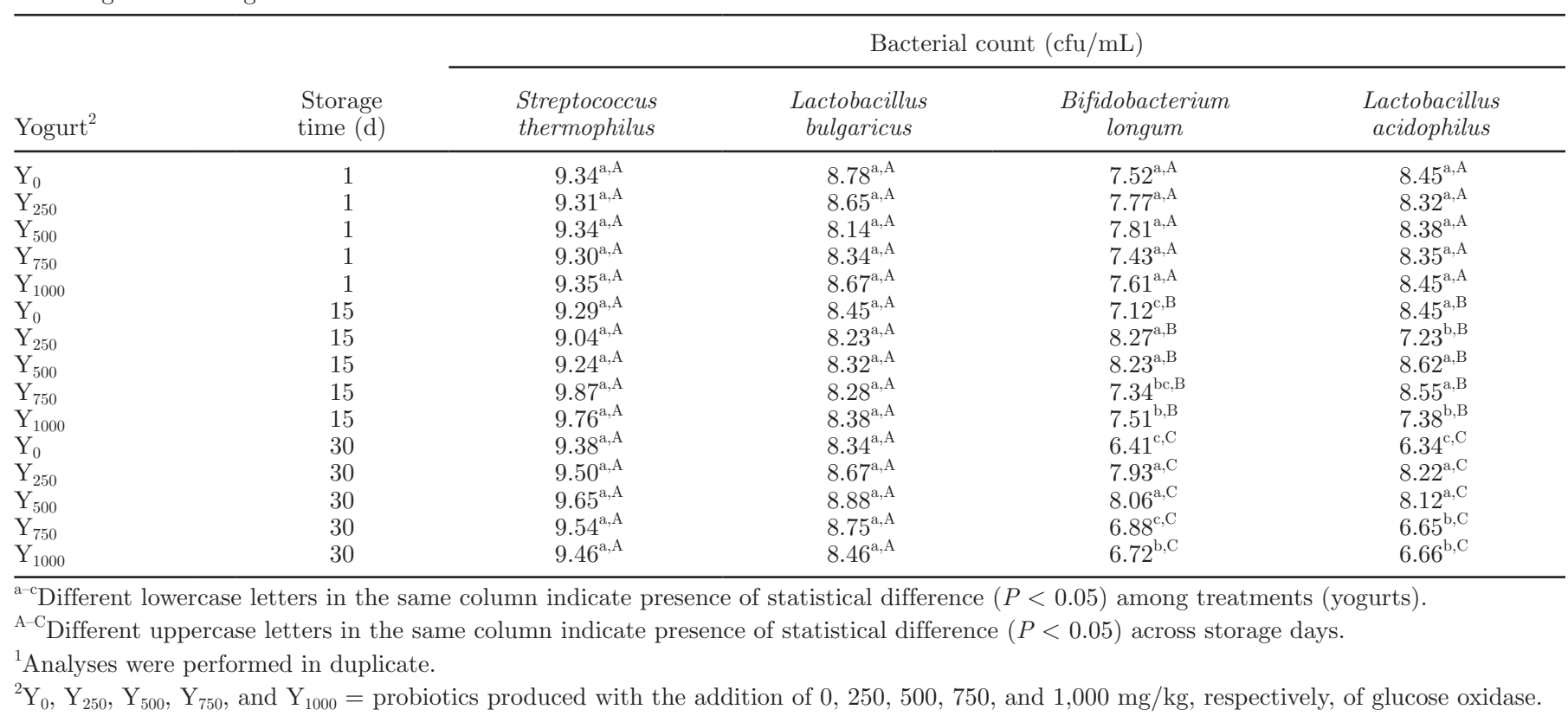

ganisms. Streptococcus thermophilus and Lb. bulgaricus counts varied from $9.04\left(\mathrm{Y}_{250}, \mathrm{~d} 15\right)$ to $9.87\left(\mathrm{Y}_{750}, \mathrm{~d} 15\right)$ and from $8.14\left(\mathrm{Y}_{500}, \mathrm{~d} 1\right)$ to $8.88\left(\mathrm{Y}_{500}, \mathrm{~d} 30\right) \log \mathrm{cfu} /$ $\mathrm{mL}$ throughout the period investigated, suggesting that the viability of the starter cultures was not influenced by the addition of the enzyme.

However, with regard to the counts of probiotic microorganisms, both the concentration of glucose oxidase and storage time $(P<0.05)$ were observed to have an effect on the viable counts of microorganisms compared with the control yogurt $\left(\mathrm{Y}_{0}\right)$. Yogurts with high concentrations of glucose oxidase $\left(Y_{750}\right.$ and $\left.Y_{1000}\right)$ showed a more rapid decrease in the numbers of both species: B. longum declined from 7.43 and 7.61 to 6.88 and 6.72 in $\mathrm{Y}_{750}$ and $\mathrm{Y}_{1000}$, respectively, whereas the $L b$. acidophilus counts declined from 8.35 and 8.45 to 6.65 and $6.66 \log \mathrm{cfu} / \mathrm{mL}$. In both cases, the reductions in the number of viable cells were comparable to the decreases observed in the control yogurt, which presented counts of 6.41 and $6.34 \log \mathrm{cfu} / \mathrm{mL}$, respectively, at the end of the storage period. These results coincided with the increase in oxygen content in the yogurt and reinforce the difficulty of minimizing oxidative stress in probiotic yogurts.

It is noteworthy that although glucose oxidase can produce hydrogen peroxide, which would cause an inhibitory effect on probiotic bacteria, the commercial enzyme product used in this study contained catalase in its formulation. This minimized any negative effect, as catalase consumes hydrogen peroxide produced during glucose oxidase action. However, it also produces oxygen, which can be incorporated throughout the refrigerated storage, and therefore may be considered a disadvantage. However, the amount produced did not seem comparable to the oxygen that permeates through the packaging during the storage. The results suggest that the addition of glucose oxidase had an overall positive effect in terms of maintaining or reducing the increase of oxygen dissolved in the probiotic yogurts compared with the control yogurt and consequently created favorable conditions for the development of probiotic microorganisms, which are intrinsically anaerobic or microaerophilic. Addition of glucose oxidase is a biotechnological option and this approach is in agreement with the tendency of the modern food industry where there is negative consensus about the inclusion of chemical compounds in foods (Behrens et al., 2010; Shim et al., 2011). Nonetheless, high levels of supplementation are not necessary given the lack of substrate available in the system. Further studies should include a consumer test aimed to check the optimal concentration at which glucose oxidase can be added to the yogurt with respect to consumer perception.

\section{Production of Lactic Acid, Acetic Acid, Diacetyl, and Acetaldehyde}

Table 3 shows the values for lactic acid, acetic acid, diacetyl, and acetaldehyde in the probiotic yogurts supplemented with increasing quantities of glucose oxidase. Overall, a positive influence of glucose oxidase and storage time $(P<0.05)$ was observed compared with the 
Table 3. Production of lactic acid, acetic acid, diacetyl, and acetaldehyde in probiotic yogurts with increased glucose oxidase concentrations during the refrigerated storage (glucose was not detected in any yogurt throughout the study) ${ }^{1}$

\begin{tabular}{|c|c|c|c|c|c|}
\hline Yogurt $^{2}$ & $\begin{array}{l}\text { Storage } \\
\text { time (d) }\end{array}$ & $\begin{array}{c}\text { Lactic acid } \\
(\mathrm{mg} / \mathrm{mL})\end{array}$ & $\begin{array}{l}\text { Acetic acid } \\
(\mathrm{mg} / \mathrm{mL})\end{array}$ & $\begin{array}{l}\text { Diacetyl } \\
(\mu \mathrm{g} / \mathrm{mL})\end{array}$ & $\begin{array}{l}\text { Acetaldehyde } \\
(\mu \mathrm{g} / \mathrm{mL})\end{array}$ \\
\hline $\mathrm{Y}_{0}$ & 1 & $5.43^{\mathrm{a}, \mathrm{A}}$ & $0.75^{\mathrm{a}, \mathrm{A}}$ & $16.7^{\mathrm{c}, \mathrm{A}}$ & $25.3^{\mathrm{c}, \mathrm{A}}$ \\
\hline $\mathrm{Y}_{750}$ & 1 & $5.37^{\mathrm{a}, \mathrm{A}}$ & $0.79^{\mathrm{a}, \mathrm{A}}$ & $23.6^{\mathrm{b}, \mathrm{A}}$ & $51.9^{\mathrm{b}, \mathrm{A}}$ \\
\hline$Y_{1000}$ & 1 & $5.18^{\mathrm{a}, \mathrm{A}}$ & $0.84^{\mathrm{a}, \mathrm{A}}$ & $41.1^{\mathrm{a}, \mathrm{A}}$ & $58.7^{\mathrm{b}, \mathrm{A}}$ \\
\hline $\mathrm{Y}_{0}$ & 15 & $4.72^{\mathrm{b}, \mathrm{B}}$ & $0.57^{\mathrm{c}, \mathrm{B}}$ & $14.4^{\mathrm{b}, \mathrm{B}}$ & $69.6^{\mathrm{a}, \mathrm{B}}$ \\
\hline $\mathrm{Y}_{750}$ & 15 & $5.62^{\mathrm{a}, \mathrm{B}}$ & $0.83^{\mathrm{a}, \mathrm{B}}$ & $17.4^{\mathrm{a}, \mathrm{B}}$ & $44.4^{\mathrm{b}, \mathrm{B}}$ \\
\hline$Y_{1000}$ & 15 & $5.95^{\mathrm{a}, \mathrm{B}}$ & $0.86^{\mathrm{a}, \mathrm{B}}$ & $13.9^{\mathrm{bc}, \mathrm{B}}$ & $28.2^{\mathrm{c}, \mathrm{B}}$ \\
\hline $\mathrm{Y}_{0}$ & 30 & $6.42^{\mathrm{b}, \mathrm{C}}$ & $0.77^{\mathrm{a}, \mathrm{B}}$ & $88.3^{\mathrm{a}, \mathrm{C}}$ & $11.3^{\mathrm{b}, \mathrm{C}}$ \\
\hline $\mathrm{Y}_{250}$ & 30 & $6.54^{\mathrm{b}, \mathrm{C}}$ & $0.52^{\mathrm{c}, \mathrm{B}}$ & $97.2^{\mathrm{a}, \mathrm{C}}$ & $23.8^{\mathrm{a}, \mathrm{C}}$ \\
\hline$Y_{500}$ & 30 & $6.77^{\mathrm{a}, \mathrm{C}}$ & $0.53^{\mathrm{c}, \mathrm{B}}$ & $88.1^{\mathrm{a}, \mathrm{C}}$ & $22.2^{\mathrm{a}, \mathrm{C}}$ \\
\hline $\mathrm{Y}_{750}$ & 30 & $7.08^{\mathrm{a}, \mathrm{C}}$ & $0.62^{\mathrm{b}, \mathrm{B}}$ & $30.9^{\mathrm{c}, \mathrm{C}}$ & $24.2^{\mathrm{a}, \mathrm{C}}$ \\
\hline$Y_{1000}$ & 30 & $7.80^{\mathrm{a}, \mathrm{C}}$ & $0.66^{\mathrm{b}, \mathrm{B}}$ & $56.4^{\mathrm{b}, \mathrm{C}}$ & $23.3^{\mathrm{a}, \mathrm{C}}$ \\
\hline
\end{tabular}

${ }^{\mathrm{a}-\mathrm{c}}$ Different lowercase letters in the same column indicate presence of statistical difference $(P<0.05)$ among treatments (yogurts).

${ }^{\mathrm{A}-\mathrm{C}}$ Different uppercase letters in the same column indicate presence of statistical difference $(P<0.05)$ across storage days.

${ }^{1}$ Analyses were performed in duplicate.

${ }^{2} \mathrm{Y}_{0}, \mathrm{Y}_{250}, \mathrm{Y}_{500}, \mathrm{Y}_{750}$, and $\mathrm{Y}_{1000}=$ probiotics produced with the addition of $0,250,500,750$, and 1,000 $\mathrm{mg} / \mathrm{kg}$, respectively, of glucose oxidase.

control yogurt. Glucose was not detected in any of the yogurts tested, suggesting that it was entirely consumed by the enzyme from the beginning of the shelf life ( $d$ 1). However, the consumption of glucose by probiotic or starter microorganisms cannot be discounted. Further studies are needed to clarify this effect.

Our results support that increased levels of glucose oxidase enhanced the metabolism of the lactic and probiotic cultures that readily benefited from the smaller quantities of dissolved oxygen due to glucose oxidase action. Obviously, in the course of the refrigerated storage, the enzyme loses its activity and the dissolved oxygen levels may increase. This effect may lower the counts of bifidobacteria and consequently decrease the acetic acid production. With regard to the characteristic aroma compounds of yogurt; that is, diacetyl and acetaldehyde, it is important that the addition of glucose oxidase does not negatively affect the typical flavor of the product. The results obtained in this study are promising in that, throughout the storage period evaluated, the yogurts with glucose oxidase were found to produce greater amounts $(P<0.05)$ of these 2 compounds compared with the control yogurt. As for diacetyl, the values determined in the experimental yogurts varied from $19.4\left(\mathrm{Y}_{250}, \mathrm{~d} 1\right)$ to $97.2\left(\mathrm{Y}_{250}, \mathrm{~d} 30\right)$ $\mathrm{mg} / \mathrm{L}$, with the control yogurt $\left(\mathrm{Y}_{0}\right)$ showing variation from 8.29 to $16.7 \mathrm{mg} / \mathrm{mL}$, respectively.

Greater production of acetaldehyde $(P<0.05)$ was also observed, which is extremely favorable because this compound is mainly responsible for the typical aroma of yogurt (Cheng, 2010). Maximum production was observed after $15 \mathrm{~d}$ of refrigerated storage, $69.6\left(\mathrm{Y}_{0}\right)$ to
$71.6\left(\mathrm{Y}_{500}\right) \mu \mathrm{g} / \mathrm{mL}$, respectively, declining to $23.3\left(\mathrm{Y}_{100}\right)$ and $13.8\left(\mathrm{Y}_{250}\right)$ at the end of the storage period. The results are coherent, because overall, probiotic bacteria do not produce aroma compounds markedly and, in general, probiotic yogurts and fermented milks are low in flavor due to the low activity of the enzyme threonine aldolase, which catalyzes the formation of acetaldehyde from the substrate, threonine (Gardini et al., 1996). The decrease in acetaldehyde levels at the end of the storage time can be related to the presence of enzyme alcohol dehydrogenase, which metabolizes acetaldehyde in ethanol. This enzyme has been detected in probiotic bacteria such as Lb. acidophilus (Marshall and Cole, 1983), and it can explain the mild flavor present in probiotic yogurts, as acetaldehyde has a lower threshold compared with ethanol.

Baranowska (2006) reported that levels of lactose and glucose present in milk did not influence the production of diacetyl and acetaldehyde in yogurt, but did influence supplementation of the yogurt with the precursors of aroma compounds. A recent study (Pinto et al., 2009) confirmed this finding when investigating the behaviors of diacetyl and acetaldehyde in yogurts processed with single and joint cultures throughout shelf life. The authors showed that the amount of each compound produced depended on the cultures used and the interactions between them. In general, the production of diacetyl was greater in yogurts fermented by Strep. thermophilus on its own, whereas the production of acetaldehyde was greater in yogurts fermented with $L b$. bulgaricus. Ott et al. (2000) report that the difference in production of flavor compounds in yogurt 
may be related to the intensity of the acidity of the products.

Recently, Martin et al. (2011) reported on the influence of the oxidoreduction potential value on the production of aroma compounds, as it can modify the metabolic pathways of the yogurt bacteria. Oxidative conditions contribute to the stability of the acetaldehyde during the yogurt storage, whereas reducing conditions provide the opposite effect.

Our approach is relevant because we observed no negative effect of glucose oxidase supplementation on production of aroma compounds in yogurt. This is crucial for its acceptance by the consumers as probiotic and conventional yogurts should be similar for consumers. In this context, adequate production of acetaldehyde and diacetyl, which are the compounds related to the typical flavor of the yogurt (Cheng, 2010), is essential.

\section{CONCLUSIONS}

The results of this study suggest that addition of glucose oxidase is a potential option for maintaining the survival of probiotic bacteria in yogurts. Yogurts with added glucose oxidase presented a lesser increase in the concentration of dissolved oxygen, along with a smaller decrease in the counts of B. longum and Lb. acidophilus, were observed. In addition, the typical yogurt aroma compounds, acetaldehyde and diacetyl, were found to be produced in adequate amounts, together with the formation of moderate amounts of organic acids, particularly lactic acid and acetic acid. Supplementation with high levels of glucose oxidase was not an adequate alternative because of the lack of available substrate necessary for its action, and higher levels of glucose oxidase enzyme resulted in higher concentrations of oxygen dissolved in the product, which, in turn, led to lower counts of lactic and probiotic bacteria. Future studies should assess the performance of probiotic yogurts supplemented with glucose oxidase and packaged in systems with different oxygen permeabilities. Furthermore, affective tests based on consumer perception should be performed to evaluate the changes in the sensory characteristics of the probiotic yogurts caused by the addition of increasing quantities of glucose oxidase.

\section{REFERENCES}

Ahn, J. B., H.-J. Hwang, and J.-H. Park. 2001. Physiology response of oxygen-tolerant anaerobic Bifidobacterium longum under oxygen. J. Microbiol. Biotechnol. 11:443-451.

Albenzio, M., A. Santillo, M. Caroprese, R. Marino, A. Trani, and M. Faccia. 2010. Biochemical patterns in ovine cheese: Influence of probiotic strains. J. Dairy Sci. 93:3487-3496.

Alegre, I., I. Viñas, J. Usall, M. Anguera, and M. Abadias. 2011. Microbiological and physicochemical quality of fresh-cut apple enriched with the probiotic strain Lactobacillus rhamnosus GG. Food Microbiol. 28:59-66.

Allgeyer, L. C., M. J. Miller, and S.-Y. Lee. 2010. Sensory and microbiological quality of yogurt drinks with prebiotics and probiotics. J. Dairy Sci. 93:4471-4479.

Almeida, M. H. B., S. S. Zoellner, A. G. Cruz, M. R. L. Moura, L. M. J. Carvalho, and A. S. Sant'Ana. 2008. Potentially probiotic açaí yogurt. Int. J. Dairy Technol. 61:178-182.

Baranowska, M. 2006. Intensification of the synthesis of flavor compounds in yogurt by milk enrichment with their precursors. Pol. J. Food Nutr. Sci. 15:5-11.

Behrens, J. H., M. N. Barcellos, L. J. Frewer, T. P. Nunes, B. D. G. M. Franco, M. T. Destro, and M. Landgraf. 2010. Consumer purchase habits and views on food safety: A Brazilian study. Food Contr. 21:963-969.

Bergamini, C. V., E. R. Hynes, M. C. Candioti, and C. A. Zalazar. 2009. Multivariate analysis of proteolysis patterns differentiated the impact of six strains of probiotic bacteria on a semi-hard cheese. J. Dairy Sci. 92:2455-2467.

Bolduc, M.-P., Y. Raymond, P. Fustier, C. P. Champagne, and J.C. Vuillemard. 2006. Sensitivity of Bifidobacteria to oxygen and redox potential in non-fermented pasteurized milk. Int. Dairy J. 16:1038-1048.

Brasil. 2007. Ministério da Agricultura, Pecuária e Abastecimento. Instrução Normativa 46 de 23/10/2007. Regulamento Técnico de Identidade e Qualidade de Leites Fermentados. Accessed April 21, 2011. http://www.agricultura.gov.br.

Burgain, J., C. Gaiani, M. Linder, and J. Scher. 2011. Encapsulation of probiotic living cells: From laboratory scale to industrial applications. J. Food Eng. 104:467-483.

Cheng, H. 2010. Volatile flavor compounds in yogurt: A review. Crit. Rev. Food Sci. Nutr. 50:938-950.

Church, F. C., H. E. Swaisgood, D. H. Porter, and G. L. Catignani. 1983. Spectrophotometric assay using o-phthaldialdehyde for determination of proteolysis in milk and isolated milk proteins. J. Dairy Sci. 66:1219-1227.

Condurso, C., A. Verzera, V. Romeo, M. Ziino, and F. Conte. 2008. Solid-phase microextraction and gas chromatography mass spectrometry analysis of dairy product volatiles for the determination of shelf-life. Int. Dairy J. 18:819-825.

Corcoran, B. M., C. Stanton, G. Fitzgerald, and R. P. Ross. 2008. Life under stress: The probiotic stress response and how it may be manipulated. Curr. Pharm. Des. 14:1382-1399.

Cruz, A. G., R. S. Cadena, J. A. F. Faria, H. M. A. Bolini, C. Dantas, M. M. C. Ferreira, and R. Deliza. 2012. PARAFAC: Adjustment for modeling consumer study covering probiotic and conventional yogurt. Food Res. Int. 45:211-215.

Cruz, A. G., R. S. Cadena, J. A. F. Faria, C. A. F. Oliveira, R. N. Calvacanti, H. M. A. Bolini, and M. A. A. P. da Silva. 2011. Consumer acceptability and purchase intent of probiotic yoghurt with added glucose oxidase using sensometrics, artificial neural networks and logistic regression. Int. J. Dairy Technol. 64:549-556.

Cruz, A. G., J. A. F. Faria, E. H. M. Walter, R. R. Andrade, R. N. Cavalcanti, C. A. F. Oliveira, and D. Granato. 2010a. Optimization of the processing of probiotic yoghurt added with glucose oxidase using the response surface methodology. J. Dairy Sci. 93:1058-1069.

Cruz, A. G., E. H. M. Walter, R. S. Cadena, J. A. F. Faria, H. M. A. Bolini, H. P. Pinheiro, and A. S. Sant'Ana. 2010b. Survival analysis methodology to predict the shelf-life of probiotic flavored yogurt. Food Res. Int. 43:1444-1448.

Dave, R. I., and N. P. Shah. 1997. Effectiveness of acid ascorbic as an oxygen scavenger in improving viability of probiotic bacteria in yogurts made with commercial starters cultures. Int. Dairy J. 7:435-443.

Dave, R. I., and N. P. Shah. 1998. Ingredient supplementation effects on viability of probiotic bacteria in yogurt. J. Dairy Sci. 81:2804-2816.

Di Criscio, T., A. Fratianni, R. Mignogna, L. Cinquanta, R. Coppola, E. Sorrentino, and G. Panfili. 2010. Production of functional pro- 
biotic, prebiotic, and synbiotic ice creams. J. Dairy Sci. 93:45554564 .

Donkor, O. N., A. Henriksson, T. Vasiljevic, and N. P. Shah. 2005. Probiotic strains as starter cultures improve angiotensin-converting enzyme inhibitory activity in soy yogurt. J. Food Sci. 70:M375-M381.

Ebel, B., F. Martin, L. D. T. Le, P. Gervai, and R. Cachon. 2011. Use of gases to improve survival of Bifidobacterium bifidum by modifying redox potential in fermented milk. J. Dairy Sci. 94:2185-2191.

Ejtahed, H. S., J. Mohtadi-Nia, A. Homayouni-Rad, M. Niafar, M. Asghari-Jafarabadi, V. Mofid, and A. Akbarian-Moghar. 2011. Effect of probiotic yogurt containing Lactobacillus acidophilus and Bifidobacterium lactis on lipid profile in individuals with type 2 diabetes mellitus. J. Dairy Sci. 94:3288-3294.

Ferraz, J. L., A. G. Cruz, R. S. Cadena, M. Q. Freitas, U. M. Pinto, C. C. Carvalho, J. A. F. Faria, and H. M. A. Bolini. 2012. Sensory acceptance and survival of probiotic bacteria in ice cream produced with different overrun levels. J. Food Sci. 77:S24-S28.

Figueroa-González, I., G. Quijano, G. Ramírez, and A. Cruz-Guerrero. 2011. Probiotics and prebiotics - Perspectives and challenges. J. Food Sci. Agric. 91:1341-1348.

Fortin, M.-H., C. P. Champagne, D. St-Gelais, M. Britten, M. P. Fustier, and M. Lacroix. 2010. Effect of time of inoculation, starter addition, oxygen level and salting on the viability of probiotic cultures during Cheddar cheese production. Int. Dairy J. 21:75-82.

Gardini, F., R. Lanciotti, M. E. Guerzoni, and S. Torriani. 1996. Evaluation of aroma production and survival of $S$. thermophilus, $L$. bulgaricus and L. acidophilus in fermented milks. Int. Dairy J. 9:125-144.

Godward, G., K. Sultana, K. Kailasaphaty, P. Peiris, R. Arumugaswamy, and N. Reynolds. 2000. The importance of strain selection on the viability and survival of probiotic bacteria in dairy foods. Milchwissenschaft 55:441-445.

Gomes, A. A., S. P. Braga, A. G. Cruz, R. S. Cadena, P. C. Lollo, C. C. Carvalho, J. Amaya-Farfán, J. A. F. Faria, and H. M. A. Bolini. 2011. Effect of the inoculation level of Lactobacillus acidophilus in probiotic cheese on the physicochemical features and sensory performance towards commercial cheeses. J. Dairy Sci 94:4777-4786

Granato, D., G. F. Branco, A. G. Cruz, J. A. F. Faria, and F. Nazarro. 2010a. Functional foods and non-dairy probiotic food development: Trends, concepts and products. Comp. Rev. Food Sci Food Saf. 9:292-302.

Granato, D., G. F. Branco, A. G. Cruz, J. A. F. Faria, and N. P. Shah. 2010b. Probiotic dairy products as functional foods. Comp. Rev. Food Sci. Food Saf. 9:455-470.

Horiuchi, H., H. Inoue, E. Liu, M. Fukui, Y. Sasaki, and T. Saaki. 2009. A method for manufacturing superior set yogurt under reduced oxygen concentration. J. Dairy Sci. 92:4112-4121.

Isik, U., D. Boyacioglu, E. Capanoglu, and D. Nilufer Erdil. 2011. Frozen yogurt with added inulin and isomalt. J. Dairy Sci. 94:16471656.

Jasson, S. E. A., C. J. Edsman, U. W. Geede, and M. S. Hedenqvist. 2001. Packaging materials for fermented milk: Effect of material crystallinity and polarity on food quality. Pack. Technol. Sci. 18:119-127.

Jayamane, V. S., and M. R. Adams. 2009. Modelling the effects of $\mathrm{pH}$, storage temperature and redox potential on the survival of bifidobacteria in fermented milk. Int. J. Food Sci. Technol. 44:11311138

Jeanson, S., N. Hilgert, M.-O. Coquillard, C. Seukpanya, M. Faiveley, P. Neveu, C. Abraham, V. Georgescu, P. Fourcassié, and E. Beuvier. 2009. Milk acidification by Lactococcus lactis is improved by decreasing the level of dissolved oxygen rather than decreasing redox potential in the milk prior to inoculation. Int. J. Food Microbiol. 131:75-81.

Johansen, S. B., T. Naes, J. Oyaas, and M. Hersleth. 2010. Acceptance of calorie-reduced yogurt: Effects of sensory characteristics and product information. Food Qual. Prefer. 21:13-21.

Kawasaki, S., T. Minura, S. Satoh, K. Takeda, and Y. Nimura. 2006. Response of the microaerophilic Bifidobacterium species, B. boum and B. thermophilum, to oxygen. Appl. Environ. Microbiol $72: 6854-6858$

Li, Q., Q. Chen, H. Ruan, D. Zhu, and G. He. 2010. Isolation and characterisation of an oxygen, acid and bile resistant Bifidobacterium animalis ssp. lactis Qq 08. J. Sci. Food Agric. 90:1340-1346. Madureira, A. R., T. Brandão, M. E. Pintado, A. M. Gomes, and F. X. Malcata. 2011a. Technological optimization of manufacture of probiotic whey cheese matrices. J. Food Sci. 76:E203-211.

Madureira, A. R., A. I. Pintado, A. M. Gomes, M. E. Pintado, and F. X. Malcata. 2011b. Protective effect of whey cheese matrix on probiotic strains exposed to simulated gastrointestinal conditions. Lebenson. Wiss. Technol. 44:75-81.

Marafon, A.P., A. Surimi, M.R. Alcântara, A. Y. Tamime, and M. N. Oliveira. 2011. Optimization of the rheological properties of probiotic yoghurts supplemented with milk proteins. Lebenson. Wiss. Technol. 44:511-519.

Marshall, R. T. 1993. Standard Methods for Examination of Dairy Products. American Public Health Association, Washington, DC.

Marshall, V. M., and W. M. Cole. 1983. Threonine and alcohol dehydrogenase activities in Lactobacillus bulgaricus and Lactobacillus acidophilus and their contribution to flavour production in fermented milks. J. Dairy Res. 50:375-379.

Martin, F., R. Cachon, K. Pernin, J. De Coninck, P. Gevais, E. Guichard, and N. Cayott. 2011. Effect of oxidoreduction potential on aroma biosynthesis by lactic bacteria in nonfat yogurt. J. Dairy Sci. 94:614-622.

Miller, C. W., M. H. Nguyen, M. Rooney, and K. Kailasapathy. 2002 The influence of packaging materials on the dissolved oxygen content of probiotic yoghurt. Pack. Technol. Sci. 15:133-138.

Miller, C. W., M. H. Nguyen, M. Rooney, and K. Kailasapathy. 2003. The control of dissolved oxygen content in probiotic yoghurts by alternative packaging materials. Pack. Technol. Sci. 16:61-67.

Minervini, F., S. Siragusa, M. Faccia, F. Dal Bello, M. Gobbetti, and M. De Angelis. 2012. Manufacture of Fior di Latte cheese by incorporation of probiotic lactobacilli. J. Dairy Sci. 95:508-520.

Mohammadi, R., M. Rouhi, and A. M. Mortazavian. 2011. Effects of music waves on fermentation characteristics and viability of starter cultures in probiotic yogurt. Milchwissenschaft 66:193-196.

Mortazavian, A. M., M. R. Ehsani, S. Sohrabvandi, and J. A. Reihemer. 2007. MRS-Bile agar: Its suitability for the enumeration of mixed probiotic in cultured dairy products. Milchwissenschaft $62: 270-272$.

Mortazavian, A. M., R. Khosrokhavar, H. Rastegar, and G. R. Mortazaei. 2010. Effect of dry matter standardization order on biochemical and microbiological characteristics of freshly made probiotic doogh (Iranian fermented milk drink). Ital. J. Food Sci 1:98-104.

Ninomiya, K., K. Matsuda, T. Kawahata, T. Kanaya, M. Kohno, Y. Katakura, M. Asada, and S. Shioya. 2009. Effect of the $\mathrm{CO}_{2}$ concentration on the growth and exopolysaccharide production of $\mathrm{Bi}$ fidobacterium longum cultived under aerobic conditions. J. Biosci. Bioeng. 5:535-537.

Odamaki, T., J. Z. Xiao, S. Yonezawa, T. Yaeshima, and K. Iwatsuki. 2011. Improved viability of bifidobacteria in fermented milk by cocultivation with Lactococcus lactis subspecies lactis. J. Dairy Sci. 94:1112-1121.

Oliveira, R. P., P. Patricia, M. N. Oliveira, and A. Converti. 2011. Effect of inulin as a prebiotic to improve growth and counts of a probiotic cocktail in fermented skim milk. Lebenson. Wiss. Technol. 44:520-523.

Oliveira, R. P. S., A. Florence, R. C. Silva, A. Converti, M. N. Oliveira, and L. A. Gioielli. 2009. Effect of different prebiotics on the fermentation kinetics, probiotic survival and fatty acids profiles in nonfat symbiotic fermented milk. Int. J. Food Microbiol 128:467-472.

Ongol, M. P., Y. Sawatari, Y. Ebina, T. Sone, M. Tanaka, F. Tomita, A. Yokoda, and K. Asano. 2007. Yogurt fermented by Lactobacillus delbruecki ssp. bulgaricus $\mathrm{H}^{+}$-ATPase defective mutants exhibits enhanced viability of Bifidobacterium breve during storage. Int. J. Food Microbiol. 116:358-366. 
Ordonez, G. A., D. Y. C. Fung, and I. J. Jeon. 2000. Effect of oxyrase $^{\mathrm{TM}}$ on the metabolic processes of lactic acid bacteria in frozen yogurt mix. J. Rapid Methods Auto. Microbiol. 8:71-81.

Ott, A., A. Hugi, M. Baumgartner, and A. Chaintreau. 2000. Sensory investigation of yogurt flavor perception: Mutual influence of volatiles and acidity. J. Agric. Food Chem. 48:441-450.

Pinto, S. M. P., M. G. Clemente, and L. R. Abreu. 2009. Behaviour of volatile compounds during the shelf-life of yogurt. Int. J. Dairy Technol. 62:215-222.

Ramchandran, L., and N. P. Shah. 2011. Yogurt can beneficially affect blood contributors of cardiovascular health status in hypertensive rats. J. Food Sci. 76:H131-136.

Rivera-Espinoza, Y., and Y. Gallardo-Navarro. 2010. Non-dairy probiotic products. Food Microbiol. 27:1-11.

Rodrigues, D., T. Rocha-Santos, S. Sousa, A. M. Gomes, M. M. Pintado, F. X. Malcata, J. M. Sousa Lobo, and A. C. Freitas. 2011. On the viability of five probiotic strains when immobilised on various polymers. Int. J. Dairy Technol. 64:137-144.

Ruiz, L., P. Ruas-Madiedo, M. Guiemonde, C. G. Reyes-Gavilán, A. Margolles, and B. Sanchez. 2011. How do bifidobacteria counteract environmental challenges? Mechanisms involved and physiological consequences. Genes Nutr. 6:307-318.

Rybka, S., and K. Kailasapathy. 1996. Media for the enumeration of yoghurt bacteria. Int. Dairy J. 6:839-850.

Salazar, N., A. Prieto, J. A. Leal, B. Mayo, J. C. Bada-Gancedo, C. G. de los Reyes-Gavilán, and P. Ruas-Madiedo. 2009. Production of exopolysaccharides by Lactobacillus and Bifidobacterium strains of human origin, and metabolic activity of the producing bacteria in milk. J. Dairy Sci. 92:4158-4168.

Sanders, M. E., and M. L. Marco. 2010. Food format for effective delivery of probiotics. Ann. Rev. Food Sci. Technol. 1:65-85.

Savard, P., B. Lamarche, M.-E. Paradis, H. Hiboutot, É. Laurin, and D. Roy. 2011. Impact of Bifidobacterium animalis ssp. lactis BB12 and Lactobacillus acidophilus LA-5-containing yoghurt, on fecal bacterial counts of healthy adults. Int. J. Food Microbiol. 149:50-57.

Saxelin, M., A. Lassig, H. Karjalainen, S. Tynkkyen, A. Surakka, H. Vapaatalo, S. Jarvenpaa, R. Korpela, M. Mutanen, and K. Hatakka. 2010. Persistence of probiotic strains in the gastrointestinal tract when administered as capsules, yogurts or cheese. Int. J. Food Microbiol. 144:293-300.
Shafiee, G., A. M. Mortazavian, M. A. Mohammadifar, M. R. Koushki, A. Mohammadi, and R. Mohammadi. 2010. Combined effects of dry matter content, incubation temperature and final $\mathrm{pH}$ of fermentation on biochemical and microbiological characteristics of probiotic fermented milk. African J. Microbiol. Res. 4:1265-1274.

Shah, N. P. 2000. Probiotic bacteria: Selective enumeration and survival in dairy foods. J. Dairy Sci. 83:894-907.

Shakirova, L., L. Auzina, P. Zikmanis, M. Gavare, and M. Grube. 2010. Influence of growth conditions on hydrophobicity of Lactobacillus acidophilus and Bifidobacterium lactis cells and characteristics by FT-IS spectra. Spectros. Int. J. 24:251-255.

Shihata, A., and N. P. Shah. 2000. Proteolytic profile of yogurt and probiotic bacteria. Int. Dairy J. 10:401-408.

Shim, S.-M., S. H. Seo, Y. Lee, M. Gui-Im, K. Min-Shik, and J.-H. Park. 2011. Consumers' knowledge and safety perceptions of food additives: Evaluation on the effectiveness of transmitting information on preservatives. Food Contr. 22:1054-1060.

Simpson, P. J., C. Stanton, G. F. Fitzgerald, and R. P. Ross. 2005 Intrinsic tolerance of Bifidobacterium species to heat and oxygen and survival following drying and storage. J. Appl. Microbiol. 99:493-501.

Talwalkar, A., and K. Kailasapathy. 2004. Oxidative stress of probiotic bacteria. Milchwissenchaft 59:140-143.

Tamime, A. Y., and R. K. Robinson. 2007. Yoghurt: Science and Technology. 2nd ed. CRC Press, Boca Raton, FL.

van de Guchte, M., P. Serror, C. Chervaux, T. Smokvina, S. D. Ehrlich, and E. Maguin. 2002. Stress responses in lactic acid bactéria. Antonie van Leeuwenhoek 82:187-216.

Yonezawa, S., J. Z. Xiao, T. Odamaki, T. Ishida, K. Miyaji, A. Yamada, T. Yaeshima, and K. Iwatsuki. 2010. Improved growth of bifidobacteria by cocultivation with Lactococcus lactis subspecies lactis. J. Dairy Sci. 93:1815-1823.

Zacarchenco, P. B., and S. M. Roig. 2004. Diferential enumeration of Bibidobacterium longum and Lactobacillus acidophilus in the presence of Streptococcus thermophilus. Milchwissenschaft 59:258-261.

Zhao, X. H., and D. Li. 2008. A new approach to eliminate stress for two probiotics with chemicals in vitro. Eur. Food Res. Technol. 277:1569-1574.

Zhu, K., Z. Fan, C. Xu, and L. Jia. 2009. Studies on impact of health factors on yogurt consumption behaviors of Beijing consumers. J. Chin. Sci. Technol. 9:185-188. 